\title{
Public Increasing Trust of Biometric Technology
}

\author{
Wara Mastoor, Priyank Nahar
}

\begin{abstract}
Publically agree to technology of biometric is compound based at extreme believe. The bounded function at believe to biometrics usually record in various types of biometrics with correlative samples associated with familiarity and confidential. To develop a complete understand trust of people recognition about biometrics, we employed current theory to develop a regular calculation of trust in biometrics from user's theory. We increased confidence of first concern in terms of mutual interaction, technology, information systems and adoption of automated technology. Identified common belief components in these circumstances. Modified objects with reference to biometric technology. Managed an Examine study to determine the reliability of this new scale for sub-factors and trust. Our statistics give rise to seventh recently elements companion with user believe to technology of biometric. We will know work process with recommend conclusion also.
\end{abstract}

Keywords: Automation Trust, Biometric Technology, Common Technology, Data Collection, Information Technology, Security, Trust of Workability.

\section{INTRODUCTION}

Technology of Biometric is a type of technique when that Scaling, collect, and powerfully inspect an individual's physical or behavioral quality. These qualities that are specific to every person could use to recognize to person. Techniques of Biometric are considered on conventional recognition models namely believable with correct detection and recognition techniques. While Technology of biometric is preferred big hard system for storing and checking public statistics, its suffers from prejudice and increase worriness and uncomfortable in the publically scales. In the example, private concerns affect public comfort levels in technology of biometric like frontier certainly televise. Securely advice for any country shows private Elements to believe in technology of details. According to publically believe with receive for technology of biometric is major finding.

Confidence is important in exactly public attitude. Previous records got that privately and believe are nearby linked to forecast public wish to secret private details. Privateness is about big reasons with technology of biometric; this element can affect public attitude purpose to work private and physical records of like techniques. Publically nature to believe mutual trust, or other singles, has an important effect on whence public believe technique in normally.

\section{Revised Manuscript Received on April 30, 2020.}

* Correspondence Author

Mrs. Wara Mastoor*, Scholar, Department of Computer Science, Shri Venkateshwara University, (U.P.), India.

Dr. Priyank Nahar, Associate Professor, Department of MCA, Shri Venkateshwara University, (U.P.), India.

(C) The Authors. Published by Blue Eyes Intelligence Engineering and Sciences Publication (BEIESP). This is an open access article under the CC BY-NC-ND license (http://creativecommons.org/licenses/by-nc-nd/4.0/)
In example, public's confidence stage related personal contrast and culture model approximates the limits to which public rely on automatism. Actually, we absorb and expand at mutual believe to increase a basic cooperation of believe in technology of biometrics and believe arbitrate accept to technology of biometric. It is believable to cooperation the public elements related relying on technology of biometric. Nevertheless, there is no orderly trustable think scale of biometric technology to our knowledge.

The lack of work checking trust in biometrics was a designation based on general correlative scales of people's agrees of this technique. We rely on present principles and scales to

(A) Mutual Trust,

(B) Technology Trust

(C) Automation Trust,

To grow with huge sophisticated scale of believe in biometrics. In previous record, we sophisticated the component companions with the four begin components of believe and applicable those in the reference by technological of biometric. Those components inbuilt:

1) Efficiency scales how services technology of biometric gives to public.

2) Point of View scale how public opinion about technology of biometric.

3) Performance scale how public to utilize technology of biometric.

4) Easiness operates how easy it is to use technology of biometric.

Our changes to check the scale with public themes and test that trust of those components in the reference are technology of biometric. We offer recent components allow to that's like of technique. We check how our clear scale forecast publically cognition of believe in techniques of biometric and how single contrast affect stage of believe.

This assignment is conduct in such a way. First, after assess previous theme, we do detail how the four begin components of belief were chosen. Second, we give details of metering things and specimen. Third, we do detail the thrice components taken out the reference of trust on technology of biometric. Finally, that is show investigate of its record, conclusion recently decision and upcoming ways.

\section{PREVIOUS PERFORM}

Previous experience perform have introduce a secresency believe behaviour target in electronic commercialese in which public are huge likely to believe and give individual details when they fully disclose the electronic commercialese website's secret policy. Biometric technology somewhat same to electronic commercialese work.

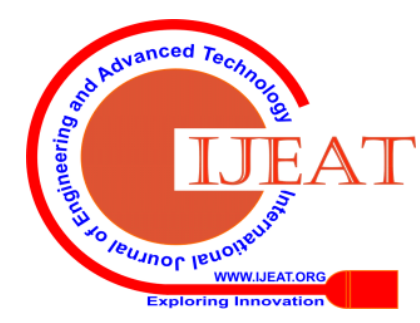


Biometrics collects publically private details and physical record for recognition motives. Whereas, this is boundation to the availability of pile up record, access to that record, access to broker who have access to the data and the perform of the record collected.

According to, public are mostly to be less confident of biometrics due to such privacy concerns. So, this is major for scholars to get the elements that help to each other to public believe in technology of biometric. According to us it's not reliable scale has been grow in the biometrics reference. But, previous literature provides trustable confidence scale in other domains. As a result, scholars have been command in growing believe scale in these estate. Although these domains are not in the reference of biometrics, these types of techniques have some similarities, specific in the domain of information collection and exchange. So we construct reliable scale in these domains and take on them in the reference of biometric techniques.

'Overview/brief/ Introduction, Review, Case study/ Study, Survey, Approach, Comparative, Analysis, Comparative Investigation, Investigation'.

\section{MUTUAL TRUST COMPONENT}

The trust is a multidisciplinary formation. Mutual trust refers to public wish to be sensitive moves of others depend on helpful hope. So, the majority of mutual studies rely on mutual trust in theoretical condition and factual work. Mutual believe is indeed in technology of biometric because this type of trust is large predictive of people's trust in entire technology. Researchers present that mutual trust in a single relationship start from the character connects with believe, and a believer in thrice types of environment: class, system, and single. In the reference of the class have component of mutual trust: behavior, credibility, competence, integrity, altruism, and tendency. In the reference of organization have component for mutual believe: honesty, sureness, decent, justice, and sensitive. In single stage of Mutual believe have scholar's testing reference the components: dependence, trust, disposition, and predictability.

Table 1. Mutual trust component from previous work

\begin{tabular}{|c|c|c|}
\hline Reference & Trust Component & $\begin{array}{l}\text { Theoretical } \\
\text { Trust } \\
\text { Component }\end{array}$ \\
\hline $\begin{array}{l}\text { Mutual trust } \\
\text { in group }\end{array}$ & $\begin{array}{l}\text { Behaviour, credibility, } \\
\text { competence, Integrity, } \\
\text { altruism, tendency }\end{array}$ & \multirow{3}{*}{$\begin{array}{l}\text { Behaviour, } \\
\text { credibility, } \\
\text { competence, } \\
\text { Integrity, } \\
\text { altruism, } \\
\text { honesty, trus }\end{array}$} \\
\hline $\begin{array}{l}\text { Mutual trust } \\
\text { in } \\
\text { organization }\end{array}$ & $\begin{array}{l}\text { Integrity, } \\
\text { Dependability, } \\
\text { Competence, Honesty, } \\
\text { Vulnerability. }\end{array}$ & \\
\hline $\begin{array}{l}\text { Individual } \\
\text { Mutual trust }\end{array}$ & $\begin{array}{l}\text { Dependence, trust, } \\
\text { Disposition, } \\
\text { Predictability. }\end{array}$ & \\
\hline
\end{tabular}

Although these references give start to many component, namely sub-factors, occupying mutual believe, something repeated in these Elements with the related technology of biometric. In example, researcher scale has organization purity by how much and how much correct information is spread between peoples. In the reference of biometrics, we can check this from a unidirectional rather than a bidirectional position as that is single link of public contribution details with technology of biometric and no other direction around. Same researcher scale tendency refer to how individual character affect the trust of position regard the trust. In the reference of biometrics, we can check the effect of individual differences in personal character and trust levels. According to, we build these previous components from the mutual trust structure as a theoretical basis for our belief scale.

\section{COMMON TECHNOLOGY FOR TRUST COMPONENT}

In studies demonstrates many empirical scale believe in reference of common technology. The scales show range to when public take and apply technology. Gives a digest of components / Elements go with from believe in common technically scale.

Table 2. Common technology trust component from previous studies

\begin{tabular}{|c|c|c|}
\hline Reference & Trust Component & $\begin{array}{l}\text { Theoretical } \\
\text { Trust } \\
\text { Component }\end{array}$ \\
\hline $\begin{array}{l}\text { Trust in mobile } \\
\text { banking } \\
\text { technology }\end{array}$ & $\begin{array}{l}\text { usefulness, reliability, } \\
\text { easiness of use, } \\
\text { quantity of information } \\
\text { and criterion pressure }\end{array}$ & \multirow{4}{*}{$\begin{array}{l}\text { Competence, } \\
\text { Easiness of } \\
\text { Use, } \\
\text { Reliability, } \\
\text { Compatibilit } \\
\text { y, } \\
\text { Usefulness, } \\
\text { Risk, } \\
\text { Behavior, } \\
\text { workability, } \\
\text { kindliness, } \\
\text { Attitude, } \\
\text { Intention, } \\
\text { Trust }\end{array}$} \\
\hline $\begin{array}{l}\text { Trust in mobile } \\
\text { banking } \\
\text { technology } \\
\end{array}$ & $\begin{array}{l}\text { Compatibility, } \\
\text { usefulness, and Risk }\end{array}$ & \\
\hline $\begin{array}{l}\text { Trust in } \\
\text { common } \\
\text { technology }\end{array}$ & $\begin{array}{l}\text { Attitude, easiness of } \\
\text { use, usefulness, } \\
\text { Performance } \\
\text { discipline, personal } \\
\text { ideals, target to take } \\
\text { technology. }\end{array}$ & \\
\hline $\begin{array}{l}\text { Trust in } \\
\text { common } \\
\text { technology }\end{array}$ & $\begin{array}{l}\text { Reliability, } \\
\text { Functionality, } \\
\text { Helpfulness, Trust }\end{array}$ & \\
\hline
\end{tabular}

Researcher was found that the usefulness, reliability, easiness of use, quantity of information and criterion pressure of public technology are meaningful in reference banking of mobile. In a same reference researcher, recognize closeness, advantages and chance are important elements to adopt the techniques. Researcher to include Elements to grow a performance scale to capture public intention to advantage technology. In task, the believe component of performance, easiness operate, advantage, performance control, personal ideals and predictions of intentions, intentions to adopt technology. In another edge of work, researcher increased a scale of believe in technique origin with mutual trust scale. These scholars recognized the types of elements: honesty, workability, kindness, and trust on common technique. We do work apply on academic and idealistic structure of those elements in field techniques of biometric. We advantage components context as an academically basis for confidence in technology of common.

Published By:

Blue Eyes Intelligence Engineering \& Sciences Publication

(C) CoDvriaht: All riahts reserved. 


\section{INFORMATION TECHNOLOGY FOR TRUST COMPONENT}

According to studied believe in technology of common, scale of believe in data technology show elements and component to same idealistic environment, too obtain to mutual believe. Confidence in data technology, a guide of believes is a famous ideological structure that built public trust regard the type qualities to technology of information. About the matter, greater trust in technology of information considers beliefs of public to make dependable record, performable, provide the sure support required. Expanding to operate, Researchers present the customer believe in technology of information such as cyberspace stores is certified on dignity. Because believe interfere chance researcher. It also opinions that publically chance interpreted are shows of believe in technology of information. So, those components span the first elements recognize in mutual believe and believe in technology of common.

Same trust component in Tables, Researchers search that easiness of operate, advantages, standard, and publically chance are elements that affect the desire to take technology of information such as internet account services. Expanding those elements, researcher serve that attitudes, personal ideals, and performance control could brief of difference in forecast public desire to use technology of information such as Internet commission services. So, include those academically models and the objects related with those scales in reference technology of biometric. Because both biometric and information technologies mostly need information contribute, there is guess that special components are well founded for biometrics.

Table 3. Information technology trust components from previous studies

\begin{tabular}{|l|l|l|}
\hline Reference & $\begin{array}{l}\text { Trust } \\
\text { component }\end{array}$ & $\begin{array}{l}\text { Theoretical } \\
\text { Trust } \\
\text { component }\end{array}$ \\
\cline { 1 - 2 } $\begin{array}{l}\text { Trust in common } \\
\text { technology }\end{array}$ & Trust & $\begin{array}{l}\text { Trust, } \\
\text { Easiness of }\end{array}$ \\
\cline { 1 - 2 } $\begin{array}{l}\text { Trust in internet } \\
\text { store }\end{array}$ & $\begin{array}{l}\text { Rise, Perception, } \\
\text { Reputation }\end{array}$ & $\begin{array}{l}\text { Reputation, } \\
\text { Risk, Attitude, }\end{array}$ \\
\cline { 1 - 2 } $\begin{array}{l}\text { Trust in online } \\
\text { banking service }\end{array}$ & $\begin{array}{l}\text { Easiness operate, } \\
\text { Performance, } \\
\text { Public standard, } \\
\text { Publically chance }\end{array}$ & $\begin{array}{l}\text { Usefulness, } \\
\text { Personal } \\
\text { ideals, } \\
\text { Behavior }\end{array}$ \\
\cline { 1 - 2 } $\begin{array}{l}\text { Trust in common } \\
\text { information } \\
\text { technology }\end{array}$ & $\begin{array}{l}\text { Attitude, } \\
\text { Subjective ideals, } \\
\text { Behavioral } \\
\text { control }\end{array}$ & \\
\hline
\end{tabular}

\section{AUTOMATION TRUST COMPONENT}

In recent research of technology of automation grow a trustable scale on that reference with the inclusion of traditional Elements depend on previous trust component of robotization. The task is enlarged with the previously statement elements like a point of view, advantage, and easiness operate, personal ideals, credibility, trust, and performance intentions that are connection with mutual trust, common technology, and information technology. In those elements, researcher recognized work pressure and compound special component for believe in robotization. Researcher was says that heavy work pressure worker utilized dependence on plain autonetics. summary of the factors discussed. related with technology of biometric. their stage of believe. In some other researcher opinion in big risk situations, workers may have likelihood to low their dependence on multiplex autonetics, but may raise their

When most the components of believe in autonetics were obtain from a process standpoint, this present to confidence in technology of biometric would too include those Elements. The plethora of perform on believe in automatics examines believe from the customer point of view. The recently technology of biometric is include into the technology of common operate by users, for example Handle and affection detect in android, we grow to believe in biometric scale of the standpoint of the customer. The theoretical concept to trust on automation and to be employed in our work reflects the

Table 4. Automation trust component from previous studies

\begin{tabular}{|l|l|l|}
\hline Reference & $\begin{array}{l}\text { Trust } \\
\text { component }\end{array}$ & $\begin{array}{l}\text { Theoretical Trust } \\
\text { component }\end{array}$ \\
\hline Believe in & Point of View, & Point of View, \\
Automation & $\begin{array}{l}\text { Advantage, } \\
\text { Easiness Operate, }\end{array}$ & $\begin{array}{l}\text { Advantage, Easiness } \\
\text { Operate, Personal }\end{array}$ \\
& Personal ideals, & ideals, honesty, trust \\
honesty, trust and & and Performance \\
& Performance & desire, Work \\
desire & pressure, Multiplex \\
\hline
\end{tabular}

\section{BIOMETRIC TECHNOLOGY TRUST COMPONENTS}

In these current trust is components of biometrics technology; we mention four components, which were common in reference of mutual believe; believe in common technology, technology of information and automation. List following components. The definitions of theoretical there are components as follows: (1) Competence mention in components is technology of biometric; (2) Point of view mention in customer's decision as regard technology of biometric depends on previous undergo and current awareness; (3) Performance mentions the customer's trust in coming performance, for example the effect techniques of biometric depends on previous undergo and current awareness. (4) Easiness operates mentions to the customers regard hard studying and using technology of biometric. It linked the objects related with these components to the elements mentioned previous. It changed these objects to mention user attitudes relying on technology of biometric. It conducted an internet learn with the common working citizens from technical workers to decide the trust of these components and in particular the age group of recent elements 
Table 5. Trust Components

\begin{tabular}{|c|c|c|c|c|}
\hline $\begin{array}{l}\text { Refer } \\
\text { ences }\end{array}$ & $\begin{array}{l}\text { Mutual } \\
\text { trust }\end{array}$ & $\begin{array}{l}\text { Common } \\
\text { Technolog } \\
\text { y }\end{array}$ & $\begin{array}{l}\text { Automatio } \\
\text { n trust }\end{array}$ & $\begin{array}{l}\text { Informat } \\
\text { ion } \\
\text { Technolo } \\
\text { gy }\end{array}$ \\
\hline $\begin{array}{l}\text { Comp } \\
\text { onent } \\
\text { s }\end{array}$ & $\begin{array}{l}\text { Behavio } \\
\text { ral, } \\
\text { credibili } \\
\text { ty, } \\
\text { compete } \\
\text { nce, } \\
\text { Integrity } \\
\text { altruism } \\
\text { Reliabil } \\
\text { ity, trust }\end{array}$ & $\begin{array}{l}\text { competence } \\
\text {, Easiness } \\
\text { operate, } \\
\text { honesty, } \\
\text { Closeness, } \\
\text { Advantage } \\
\text { Chance, } \\
\text { Behavioral, } \\
\text { Workabilit } \\
\text { y, } \\
\text { Hopefulnes } \\
\text { s, Point of } \\
\text { View, } \\
\text { Desire, } \\
\text { Trust }\end{array}$ & $\begin{array}{l}\text { Attitude, } \\
\text { Usefulness, } \\
\text { Easiness to } \\
\text { Use, } \\
\text { Personal } \\
\text { ideals, } \\
\text { Reliability, } \\
\text { trust, } \\
\text { Behavioral, } \\
\text { Intension, } \\
\text { Workload, } \\
\text { Complexity }\end{array}$ & $\begin{array}{l}\text { Trust, } \\
\text { Easiness } \\
\text { operate, } \\
\text { Reputatio } \\
\text { n, Risk, } \\
\text { Attitude, } \\
\text { Advantag } \\
\text { e, } \\
\text { Personal } \\
\text { ideals, } \\
\text { Behavior } \\
\text { al }\end{array}$ \\
\hline $\begin{array}{l}\text { Speci } \\
\text { al } \\
\text { Comp } \\
\text { onent } \\
\text { s }\end{array}$ & $\begin{array}{l}\text { Integrity } \\
\text {, } \\
\text { credibili } \\
\text { ty, } \\
\text { altruism }\end{array}$ & $\begin{array}{l}\text { Helpfulness } \\
\text { Honesty }\end{array}$ & $\begin{array}{l}\text { Workload } \\
\text { Complexity }\end{array}$ & $\begin{array}{l}\text { Reputatio } \\
\text { n }\end{array}$ \\
\hline $\begin{array}{l}\text { Share } \\
\text { d } \\
\text { Comp } \\
\text { onent } \\
\text { s }\end{array}$ & $\begin{array}{l}\text { Behavio } \\
\text { ral, } \\
\text { compete } \\
\text { nce }\end{array}$ & $\begin{array}{l}\text { Easiness } \\
\text { operate } \\
\text { Point of } \\
\text { View, } \\
\text { competence } \\
\text { Behavioral }\end{array}$ & $\begin{array}{l}\text { Point of } \\
\text { View, } \\
\text { Easiness } \\
\text { operate }\end{array}$ & $\begin{array}{l}\text { competen } \\
\text { ce, } \\
\text { Behavior } \\
\text { al, } \\
\text { Easiness } \\
\text { operate }\end{array}$ \\
\hline
\end{tabular}

\section{BEGINNING SCALE OF STRUSCTURE}

Previous research had an opinion "components sampling" technique that considers a prebuilt component of context for all average begin with selects applicant objects that can honestly show this province. According to, some three following process was used to structure the object for the mean trustable scaling and to set up its context time limit.

1) The similar aspects of four begin believe components were recognize by concept there in the reference technology of biometric.

2) Object from the previous trust studies that reflect each begin trust component and were improve to low meaning extend along to objects.

3) First scale object that best matched the begin trust component and specially related to the reference technology of biometric.

Recently objects were made to show the believe stage from the customer's point of view. Mostly objects were rearranged to common technology of biometric. The make sure that the mean of trust objects are not unique to a single type technology of biometric. So lowering other existing angle in the believe components, for example single choice. The numeric objects for the present believe components approximately 20 to 30 . This number makes sure that surveyors can finish all items in 5 to 10 minutes to achieve the desired trustability. In addition, it is important to keep our scales as small as possible to reduce reactive tiredness.

The first stage of scales structure need to specifying objects for all four believe components: competence, Point of view, performance, and easiness operates. Efficiency mention to the customer's belief that technology of biometric require the functionality, and linkup mostly customer's require. Point of view mention to the customer's decision to technology of biometric depends on preexisting awareness and personal user information and previous undergo concerns. Performance is recognizing as whatever the technique wants to use customer depends on their current awareness. Easiness operate is recognize whatever the technique show kindness and advantages to the customer's concerns and require, and built a harmonious effort to address customer concerns. The second stage, the previous research believe scales objects were mentioned again. From the previous belief scale, objects that met the three conditions were choosing. Objects were selected based on whether they are following,

(1) Inspection single out of four begin components of believe, (2) Can be pickup to assess customer confidence in technology of biometric.

(3) Didn't overhang with other studies. Objects with enough mean overhangs were mixed in a one object. In example, in object "Technique is differently very fast for me. It is not easy to put up with the advance in technique. One was cluster into single "easiness operates" object. Each object was specially designed to connect to the reference technology of biometric with the customer as a trust to some point liker scale lineup from "heavily not agree" to "heavily agree". The end stage was to low the begin object to some objects showing all of the four components of believe. This object reduce with pure organized are

(1) Directly changing the reference of biometric technology.

(2) Complete rewriting of objects.

\section{WORK PROCESS}

The members for this test were adventure physics women workers. The members were approximately 110 to150 randomly choose to workers from the country and approximately 110 to 150 randomly choose to workers from our country also. An observe engage direction generated. The intro underscored the goal of the studies, supplied to engage an online observe test, an encourage, present some members approximately 0.5 to 0.7 after completing the observe. The members were women with an average age of 30 years above. Every members give a brief speech about the techniques of biometric before complete the observe objects. Members asked to give their suggestion about every speech related with the operators standpoint to technology of biometric.

\section{ACHIEVEMENT WITH EXAMINE}

Trustable examine was show on the reaction for each of the four starting components. The imbalance all scales objects standard reaction reached between normal deliver quality for mechanical data. Starting trustable scale were formulated as a four factors, with some objects scale competence, some objects scale attitude, some objects scale behavior, some objects scale easiness of use, and some normal trust scale biometric technique. Scale in Trustability examine is shown. These reactions are observed trustable.

Published By:

Blue Eyes Intelligence Engineering \& Sciences Publication

(C) Cobvriaht: All riahts reserved.

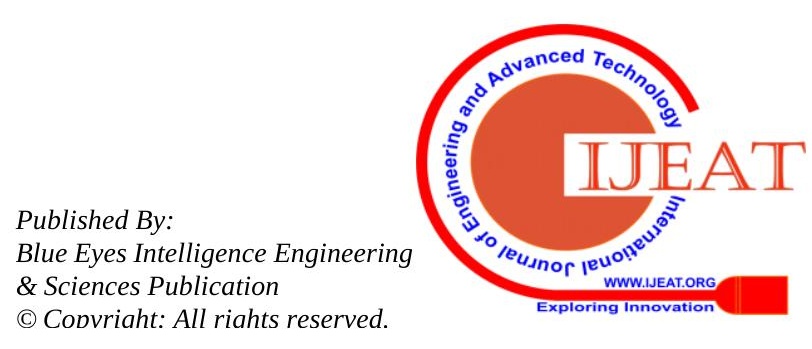


New features were quote by join main components examine with normally spin method. Three new factors with a geometrically more than some were quote, because some is assumed to be a standard geometrically, so standard more than some is assumed. The new three elements describe of the difference related to believe in biometric.

Table 6. Trustability for beginning components

\begin{tabular}{|l|l|l|l|}
\hline $\begin{array}{l}\text { Beginning } \\
\text { components }\end{array}$ & $\begin{array}{l}\text { resear } \\
\text { cher }\end{array}$ & $\begin{array}{l}\text { Researche } \\
\text { r some } \\
\text { standard } \\
\text { objects }\end{array}$ & $\begin{array}{l}\text { Some } \\
\text { number } \\
\text { of } \\
\text { objects }\end{array}$ \\
\hline Competence & 0.945 & 0.941 & 8 \\
\hline Point of View & 0.985 & 0.987 & 8 \\
\hline Performance & 0.984 & 0.985 & 6 \\
\hline Easiness operate & 0.979 & 0.890 & 6 \\
\hline
\end{tabular}

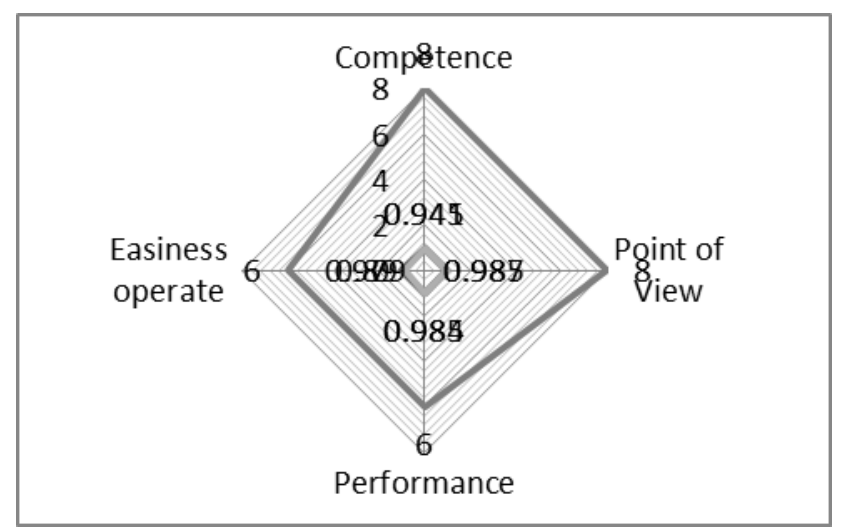

Table 6 Graph. Trustability for beginning components

Table 7. Trustability for quote components

\begin{tabular}{|l|l|l|l|}
\hline $\begin{array}{l}\text { Quote } \\
\text { components }\end{array}$ & $\begin{array}{l}\text { Resear } \\
\text { cher }\end{array}$ & $\begin{array}{l}\text { Researchers } \\
\text { some Standard } \\
\text { objects }\end{array}$ & $\begin{array}{l}\text { Some } \\
\text { number of } \\
\text { objects }\end{array}$ \\
\hline Element 1 & 0.979 & 0.989 & 20 \\
\hline Element 2 & 0.985 & 0.988 & 8 \\
\hline Element 3 & 0.926 & 0.928 & 7 \\
\hline
\end{tabular}

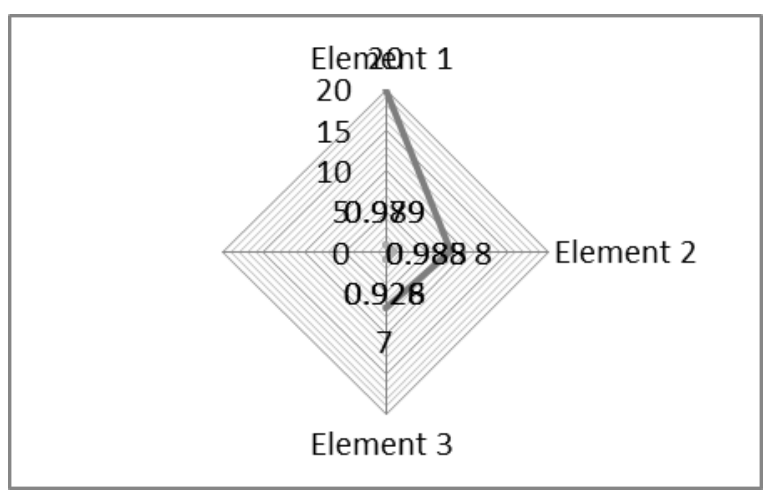

Table 7 Graph. Trustability for quote components

The spin components grid was used to examine the elements filling for every object. The result of the spin components grid will be used to filter our objects for future observed research. Some factors fill and new group objects, we characterized Element I is "Workability", Element II is "Target" and Element III is "Easiness operate". Workability is explained believe of users at technology of biometric depends because the technologies have find mostly of the requirements of users. According to matter, safety and privately could accept single of the major components in workability from observed statistics. For example, the objects "Technology of Biometric protects publically tenure the most time.", "I will use to techniques of biometric skillfully to gain private details." and "I think personal information Useful biometric techniques in the management of ". The high filling element for element I opinion about safety and privately are greatly affected when public use to technology of biometric. Target explains is the wishes of users to change and employed to technology of biometric. For example, "I read about advances in biometric technology." And use to wish and shows the trust of users of biometric technology by collect huge Statistics about technology of biometric. Easiness operate is explained to difficult stage for public to operate technology of biometric. Difference types of techniques, easiness operate could explain to benefits of biometric. According to matter, operators were huge worried for difficult stage to technology of biometric and the difficult stage to collecting details technology of biometric.

Table 8. Mechanical data collection factor examine achievement

\begin{tabular}{|c|c|c|c|}
\hline \multicolumn{4}{|c|}{ Spin Components Grid } \\
\hline & \multicolumn{3}{|c|}{ Components } \\
\hline & I & II & III \\
\hline $\begin{array}{l}\text { I normally rely on biometrics } \\
\text { techniques }\end{array}$ & .836 & & \\
\hline $\begin{array}{l}\text { I will use the camera face catch } \\
\text { function to take pictures }\end{array}$ & .696 & & \\
\hline $\begin{array}{l}\text { I will use the iris scan function to } \\
\text { entry my costly laptop }\end{array}$ & .544 & .735 & \\
\hline $\begin{array}{l}\text { I will use the figure print scan } \\
\text { function to entry my bank account }\end{array}$ & .665 & & \\
\hline $\begin{array}{l}\text { I will use voice control system to } \\
\text { drive the car }\end{array}$ & & .820 & \\
\hline $\begin{array}{l}\text { I will use a voice recognition typing } \\
\text { system to write an essay }\end{array}$ & & & .705 \\
\hline $\begin{array}{l}\text { Biometric technology has the } \\
\text { competence to meet mostly user } \\
\text { needs }\end{array}$ & .737 & & .535 \\
\hline Biometric can give best service & .792 & & \\
\hline $\begin{array}{l}\text { Biometric technology makes daily } \\
\text { life more suitable }\end{array}$ & .798 & & \\
\hline I like to use biometric technology & .796 & .533 & \\
\hline $\begin{array}{l}\text { I look ahead to using biometric } \\
\text { technology more daily }\end{array}$ & .758 & & \\
\hline $\begin{array}{l}\text { Biometrics technology protects } \\
\text { users' information most of the time }\end{array}$ & .888 & & \\
\hline $\begin{array}{l}\text { Biometric technology makes } \\
\text { personal information more private }\end{array}$ & .752 & & \\
\hline $\begin{array}{l}\text { It is not frustrating for me to use } \\
\text { biometric technology }\end{array}$ & & & .778 \\
\hline $\begin{array}{l}\text { I mean to use the latest biometric } \\
\text { technology in the next year }\end{array}$ & .649 & .699 & \\
\hline $\begin{array}{l}\text { I plan to use the latest biometric } \\
\text { technology in some time }\end{array}$ & .727 & .655 & \\
\hline
\end{tabular}




\begin{tabular}{|l|l|l|l|}
\hline $\begin{array}{l}\text { I will use to techniques of biometric } \\
\text { skillfully to gain private details. }\end{array}$ & .809 & & \\
\hline $\begin{array}{l}\text { The use of biometrics technology is } \\
\text { completely under my control }\end{array}$ & .678 & & \\
\hline $\begin{array}{l}\text { I think that biometric techniques } \\
\text { useful in managing personal } \\
\text { information }\end{array}$ & .889 & & \\
\hline $\begin{array}{l}\text { I get thrilled when I use a new } \\
\text { biometric technique }\end{array}$ & .530 & .777 & \\
\hline $\begin{array}{l}\text { I read about advances in biometric } \\
\text { technology }\end{array}$ & & .830 & \\
\hline $\begin{array}{l}\text { Totally I agree biometric } \\
\text { technology is easiness to use }\end{array}$ & .578 & & .653 \\
\hline $\begin{array}{l}\text { I wouldn't be afraid to use biometric } \\
\text { technology }\end{array}$ & & & .682 \\
\hline $\begin{array}{l}\text { It is not difficult to keep up with } \\
\text { advances in biometric technology }\end{array}$ & & & .887 \\
\hline $\begin{array}{l}\text { I use to do biometric technology is } \\
\text { compatible with other technology }\end{array}$ & .696 & & \\
\hline
\end{tabular}

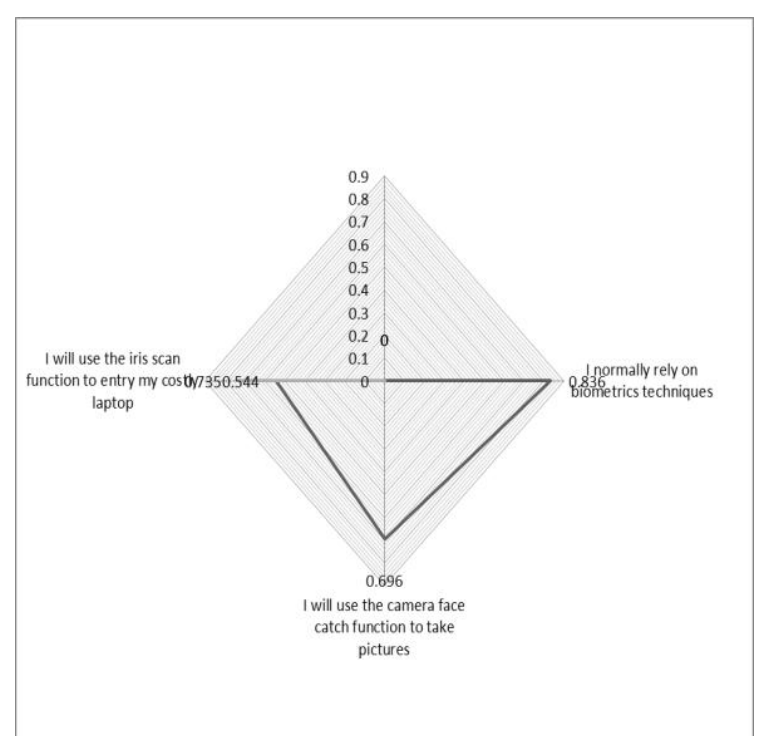

Table 8 Graph. Mechanical data collection factor examine achievement

\section{RESULT AND DISCUSSION}

Technology of Biometrics is a Unique technology for large of public because it has been applied increase to trust public to places for long duration. Technology of Biometric utilize in security systems has more components and achievements. It has more benefit that can change our living style, like: workability security and recognition identity of public person, easiness operate, information safety data and produce to life huge pleasant.

May be in that security system of biometric has some worry to information security, physical security, and public objections but consumer can't refuse the think that this unique technology wills pleasant make new our life.

The biometric recognition is mention in public systems of country important, the administration all levels to trust of the biometric techniques in identification, management details, public elements, and check of quality.

Technology of biometric showed to different form of the individually features of best procedure of assess and continue big system on top of more time.
It is major to control the reliability of the whole procedure preferable than focus on the assessment of a trustable biometric features of the serious situation. Structures that operate biometric recognition to all types are commonly to plan with other methods for increase trust such as: Competence, Point of View, Performance, Target, Workability and Easiness operate.

\section{CONCLUSION}

Our motivation of grow and prove a device to scale operators believe in technology of biometric. Scale built most important stages with surely test because the worth of the objects of scale decide the limit to observed conclusion are important and exactly. In beginning technology of biometric was not directly trustable upon. Begin three Elements was build, depend the four beginning components to believe observe to previous believe scales in biometric technology references. The growing of a trustable scale in study examine the effect of social Element in depend on technology of biometric. In coming research we will test how social standard related normal social believe effect the effects of depend on technology of biometric. I hope to conclusion of the testing to give a trustable biometric device that catches to natural prelife of believe in biometrics over social. Recently scales point on biometric technology in common, and depend from a user's point of view. In coming time, we prepare to do test on believe to change different types technology of biometric. I will test trust of people's feelings so it is need to apply technology of biometric. In the last, single of the pleasant and advance size machine study, I can systematically up and low believe to technology of biometric operators depend on their offer components. I hope precise disconnection between up to down believe in technology of biometric operators.

\section{REFERENCES}

1. Biometric Devices Technology - The experience \& expertise you can trust leading information by Star link communication Pvt. Ltd.

2. Compassionate super intelligence al with block chain, BMI, Drone, IoT and Biometric Technologies, Al-5.0, Author by - Amit Roy, PhD-2018, founder compassionate Al Lab published by Inner Light Publisher.

3. Aadhar cumulative registrations, bn India's population 2016, 1.3 bn leaders april 15th 2017 information by the BJP government qualms.

4. Selfie Biometrics Technology - security, privacy and usability challenges by Ajita Rattani, Reza Derakhshani, Arun Ross editors published by Springer link.

5. The Biometric Computing - recognition and registration, Author by Karm Veer Arya, Robin Singh Bhandoria Published by CRC Press Taylor \& Francis Group.

6. Adopting Biometric Technology - Challenging and Solution, Author by Ravindra Das Published by CRC Press Taylor \& Francis Group.

7. India has among the highest rates of fingure print in 2018, information by the economic times, published by Bennett, Coleman \& Co. Ltd.

8. Bio - IDiom - NEC's - Biometric Authentication Brand - Special issue values creation using biometrics, information by NEC Press orchestrating a brighter world.

9. Security Cyber, Author by Samir khan 2017 Published by ORF (observer research foundation) Special Report.

10. Biometrics a very short introduction Author by Michael Fair Hurst Published by Oxford University Press.

11. What are windows Hello? Microsoft's biometrics Security System, Author by Matt Kapko and Mathew Finnegan, Nov 26 2018, Information by Computerworld.india, Press form IDG Communications.

\section{Published By:}

Blue Eyes Intelligence Engineering \& Sciences Publication

(C) Cobvriaht: All riahts reserved. 
12. Protect Your Online Identity Like Your Virginity, Author by

- Abhishek Singh Rajpurohit, Published by - Notion Press.com

\section{AUTHORS PROFILE}

Mrs. Wara Mastoor I have done UG in the Science (BSc). And I followed it MSc(IT) with MCA. I have six years teaching experience and five years corporate designer in companies like high-tech healthcare and matrix global, New Delhi. Currently I am Scholar M.Phil(CS) of Computer Science department from Shri Venkateshwara University, U.P.

Dr. Priyank Nahar pursued his UG in the Computer Application(BCA). He followed it with MCA, M.Phil(CS), Ph.D(CS). He has over 14 years of Teaching Experience. He work as a corporate trainer in companies like Hewlett Packard and Integer Software, Bangalore. He has attend more than 5 FDPs/seminars and conferences. He has written 5 research papers in international and national journals. He has also authored 13 books on paper solution series along with the book on VB.Net for BCA students. Currently he is an associated with MCA department as an Associate Professor.

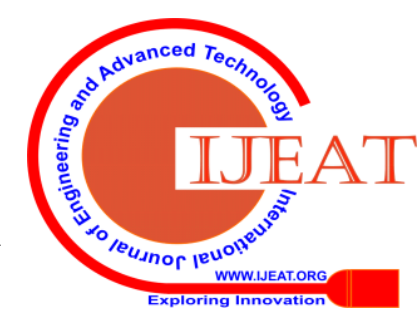

